\title{
DIASPORA AUSTRONESIA DI INDONESIA BERDASARKAN TINGGALAN RANGKA MANUSIA
}

\author{
Austronesian Diaspora in Indonesia Based on Human Skeletal Remains
}

\author{
Harry Widianto, Sofwan Noerwidi \\ Balai Arkeologi Provinsi DI Yogyakarta \\ Jalan Gedongkuning No. 174, Rejowinangun, Kec. Kotagede, \\ Kota Yogyakarta, Daerah Istimewa Yogyakarta 55171 \\ E-mail: harrywidianto58@gmail.com
}

\begin{abstract}
Austronesian migration since 4,500 years ago is an amazing phenomenon in the history of human civilization, related to the vast area and the time of spreading in the Indonesian Archipelago. There are not so many papers that summarize the Austronesian traces from paleoanthropological perspective. This paper describes the Austronesian diaspora in the archipelago, based on the physical characteristics of the human remains (especially craniodental), found in the archaeological context. Human remains with neolithic burial context were found in several cave sites on the karstic mountains at around 3,500 years ago, while skeletal remains with a paleometallic burial context were found from several coastal jar burial sites dating back to 2,000 years ago. In the future, intensive research is needed to determine whether the two different burial characteristics are the result of cultural evolution or reflects two layers of migration.
\end{abstract}

Keywords: Austronesia, diaspora, human skeletal

\section{Abstrak}

Migrasi Austronesia sejak 4.500 tahun lalu merupakan suatu fenomena mengagumkan dalam sejarah peradaban manusia, yang mencakup luasan wilayah dan kecepatan persebarannya di Kepulauan Nusantara. Namun saat ini belum banyak tulisan yang merangkum jejak Austronesia di Kepulauan Nusantara berdasarkan sudut pandang paleoantropologis. Makalah ini memaparkan diaspora Austronesia di kepulauan ini, berdasarkan ciri fisik karakter sisa-sisa rangka manusia, khususnya bagian tengkorak dan gigi geligi yang ditemukan dalam konteks arkeologis. Sisa rangka manusia dengan konteks penguburan neolitik ditemukan di beberapa situs gua pegunungan karst dari periode sekitar 3.500 tahun lalu, sedangkan sisa rangka dengan konteks penguburan paleometalik diperoleh dari beberapa situs kubur tempayan tepi pantai sejak 2.000 tahun lalu. Pada masa mendatang perlu dilakukan penelitian intensif agar diketahui apakah dua karakter penguburan berbeda periode tersebut merupakan hasil evolusi budaya atau mencerminkan dua layer migrasi manusia.

Kata kunci: Austronesia, diaspora, rangka manusia

\section{PENDAHULUAN}

\section{Austronesia dari Linguistik keArkeologi}

$\mathrm{D}$ ewasa ini, populasi Kepulauan Nusantara-dengan lebih dari 17.000 pulau di dalamnya-dihuni oleh lebih dari 266 juta jiwa, yang didominasi oleh sedikitnya 350 kelompok etnis. Di dunia, populasi ini menempati urutan ke-empat setelah China, India, dan Amerika Serikat. Pruralsitas etnis 
yang demikian tersebut telah melahirkan istilah "unity in diversity" bagi kepulauan ini, sebuah negara satu bahasa nasional dengan 756 bahasa daerah, terbanyak kedua di dunia setelah Papua Nugini.

Sebagai bangsa yang akbar, populasi Indonesia saat ini adalah bagian dari persebaran para penutur bahasa Austronesia, yang menyebar dan menghuni berbagai pulau di hamparan luas Samudra Hindia dan Pasifik (Tryon, 1995). Mereka adalah para penjelajah dua samudra, para navigator dan penakluk laut yang perkasa. Ditafsirkan berasal dari Taiwan sekitar 5.000 tahun yang lalu, bahasa Austronesia adalah ibu bahasa mereka. Dalam perspekstif biologis, para penutur Austronesia ini termasuk Ras Monggolid (Matsumura \& Oxenham, 2014).

Populasi baru ini-pengganti populasi Ras Australomelanesid yang menghuni gua-gua di Indonesia para periode 15.000 hingga 5.000 tahun silam-langsung secara cepat menghuni Kepulauan Nusantara. Mereka segera menyebar dan menghuni berbagai pulau di hamparan luas Samudra Hindia dan Samudra Pasifik, pulau besar maupun kecil. Mereka lah para penjelajah dua samudra itu, para navigator dan nomad laut yang perkasa, menaklukkan pulau demi pulau, dengan mega populasi saat ini yang melebihi 300 juta jiwa! Ditafsirkan berasal dari Taiwan, mereka saat ini tersebar sangat luas hingga Madagaskar di barat, Selandia Baru di selatan, dan Kepulauan Pasifik di timur (Bellwood, 2017). Persebaran populasi ini di Asia Tenggara kepulauan, digolongkan dalam ras Ras Monggolid Selatan, dengan ciri fisik, darah, dan ciri lainnya yang membentuk kompleksitas yang khas.

Bahasa Austronesia adalah ibu bahasa mereka. Itulah sebabnya, mereka disebut pula sebagai penutur bahasa Austronesia.
Penaklukan megah dua samudra yang berlangsung selama sekitar 6.000 tahun lamanya, hampir pasti dilakukan dengan memakai perahu, mungkin jenis perahu bercadik. Mereka mengenalkan budaya neolitik sebagai budaya baru dari tanah lahir mereka, yang kemudian diadopsi dengan budaya asli tanah taklukan melalui inovasi-inovasi teknologi. Maka segeralah tersebar luas budaya bercocok tanam awal di segala penjuru, dicirikan oleh pembuatan alat-alat batu kapak persegi yang digosok dan diupam, domestikasi tanaman dan binatang, dan mengembangkan pembuatan gerabah ber-slip merah (Bellwood, 2005). Gerabah Lapita yang terkenal adalah buah tangan mereka, yang saat ini sangat marak ditemukan di separuh wilayah sebaran mereka di daerah utara-timur.

Mereka sampai di Indonesia minimal sejak 4.000 tahun silam, yang merupakan bagian dari migrasi para penutur Austronesia dari Taiwan dan cepat menyebar ke selatan di Filipina dan Indonesia, sebelum akhirnya mencapai Pasifik pada sekitar 2.000 tahun lalu. Jalur migrasi para penutur Austronesia ini disebut sebagai teori "Out of Taiwan", yang juga menyebutkan daerah China Selatan, sekitar Fujian atau Zhejiang, sebagai tempat asli mereka sebelum bergerak ke Taiwan (Bellwood, 2017; Blust, 2009). Apabila dilihat dari kecepatan luar biasa para migran ini dalam mencapai Polinesia yang hanya ditempuh dalam waktu 2.000 tahun, maka teori "Out of Taiwan" (Bellwood, 2014) disebut pula sebagai "Express Train to Polynesia” (Diamond, 2013).

Makalah ini akan mengelaborasi diaspora Austronesia di Kepulauan Nusantara, langsung dari pencipta budaya tersebut, yaitu berdasarkan sisa-sisa rangka manusia mereka. Sebagian besar ditemukan di berbagai gua permukiman prasejarah, 
dan beberapa di antaranya dari luar gua. Untuk sampai pada inti pembahasan tentang Austronesia, akan diberikan gambaran singkat tentang proses hunian manusia di kepulauan ini, sebelum para migran Austronesia itu hadir di sini, sebagai sebuah proses migrasi yang pernah terjadi, dari jaman yang paling tua, Awal Plestosen.

\section{Migrasi Sebelum Hadirnya Para Penutur Austronesia di Kepulauan Nusantara}

Kisah penghunian Kepulauan Nusantara oleh mamalia dan kemudian manusia, sangat panjang riwayatnya. Meski konfigurasi aktual kepulauan ini baru terbentuk pada berakhirnya Zaman Es sekitar 11.000 tahun yang lalu, namun riwayat kolonisasi terhadap kepulauan ini sudah bermula sejak sekitar 2.4 juta tahun yang lalu ketika pulau Jawa baru terangkat pada bagian baratnya (Sémah, 1986 ; von Koenigswald, 1935). Fosil Archidikodon sp dari Jawa Barat merupakan fosil mamalia tertua penghuni Jawa, sebelum akhirnya ditemukan berbagai spesies dari Fauna Cijulang di Ciamis dan Fauna Kali Glagah di Bumiayu (van der Maarel, 1932). Jenis-jenis Sinomastodon sp., Hexaprotodon sp., keluarga Cervidae, beberapa spesies dari Bovidae, dan juga Geochelon sp., merupakan spesies tua yang mendiami daerah Bumiayu pada sekitar 2 juta tahun yang lalu (de Vos, 1985).

Secara perlahan, Pulau Jawa segera terangkat dan menunjukkan konfigurasi saat ini sejak 1.65 juta tahun lalu akibat gerakan lempeng tektonik, erupsi gunung berapi, fluktuasi air laut akibat glasial-interglasial, dan pelipatan Pegunungan Kendeng (van Bemmelen, 1949). Homo erectus, dari tingkatan evolutif yang paling tua hingga yang paling maju yaitu Homo erectus arkaik, Homo erectus tipik, dan Homo erectus progresif, telah hadir sangat dini di Pulau Jawa -tetapi tidak di pulau lainnya di Nusantara- mulai 1.8 juta tahun yang lalu (Widianto, 2001, 2019). Mereka berevolusi ke dalam 3 tingkatan evolutif selama tidak kurang dari 1.5 juta tahun yang lalu, dan punah pada 100.000 tahun silam (Rizal et al., 2019), sebelum digantikan oleh Homo sapiens yang hadir di kepulauan ini pada sekitar 70.000 tahun yang lalu (Westaway et al., 2017).

Manusia Modern Awal (MMA) menggantikan Homo erectus, diwakili oleh fosil Wajak dari Jawa Timur (Jacob, 1967) dan Lida Ajer dari Sumatera Barat (Westaway et al., 2017). Kedua spesimen ditafsirkan hidup sejaman pada akhir Kala Plestosen sejak 73.000 tahun yang lalu hingga sekitar 20.000 tahun silam, berdampingan dengan "The Deep Skull" dari Goa Niah di Serawak (Hunt, Gilbertson, \& Rushworth, 2007), sisa-sisa manusia dari Goa Tabon di Palawan (Détroit et al., 2004) dan juga tengkorak-tengkorak dari Goa Moh Khiew (Choosiri, 1996). Data terbaru penemuan MMA berasal dari situs hunian goa di jajaran pegunungan karst Gunung Sewu, yaitu di Goa Song Terus di Pacitan (Sémah et al., 2004). Berbeda dengan pendahulunya Homo erectus yang hidup di alam terbuka, MMA ini terindikasi sebagai penghuni goa yang sejati dan tetap melaksanakan perburuan binatang dengan alat-alat paleolitik nya seperti pendahulu mereka.

Distribusi lateral manusia di Kepulauan Nusantara hingga sekitar 5.000 tahun yang lalu menunjukkan pola hunian goa prasejarah oleh keturunan MMA, yaitu populasi Ras Australomelanesid, sejak setidaknya 15.000 tahun yang lalu dan berakhir sekitar 5.000 tahun yang lalu, di jajaran karst Pegunungan Selatan Jawa (Widianto, 2002). Beberapa bukti menunjukkan bahwa Ras 
Australomelanesid tidak punah sama sekali, akan tetapi menembus hingga 1.000 tahun silam, contohnya Kubur Tempayan di Anyer (Jacob, 1964). Seperti halnya pendahulu mereka MMA, Ras Australomelanesid juga merupakan penghuni goa, dengan melakukan perburuan binatang kecil -di Pulau Jawa didominasi oleh perburuan kera ekor panjang (Macaca sp)- dengan mengembangkan teknologi alat serpih, maupun alat-alat tulang berupa spatula dan lancipan (T. Simanjuntak, 2002).

Persebaran Ras Australomelanesid ini cukup luas di Kepulauan Nusantara, terutama pada goa-goa hunian di jajaran karst Gunung Sewu, Pegunungan Kendeng Utara di Jawa Timur, maupun Pegunungan Bogor Utara di Jawa Barat. Di Kalimantan, sisa-sisa mereka terutama diidentifikasi dari beberapa gua di Pegunungan Meratus, Kalimantan Selatan, antara lain di Gua Babi dan Gua Tengkorak (Widianto, Simanjutak, \& Toha, 1997). Selebihnya juga ditemukan pada beberapa goa di Nusa Tenggara Barat dan Nusa Tenggara Timur, serta bukit sampah (kjökken-möddinger) di pesisir timur Sumatera Utara, dan juga Gua Harimau di Sumatera Selatan (Widianto, 2009).

Pada sekitar 4.000 hingga 3.500 tahun yang lalu, populasi Ras Australomelanesid secara teoritis digantikan oleh jenis manusia modern yang paling aktual, yaitu populasi Ras Monggolid yang masih berlangsung hingga saat ini (Matsumura, Oxenham, Simanjuntak, \& Yamagata, 2017). Di bagian selatan Wallacea, yaitu di Nusa Tenggara Barat dan Timur, Ras Australomelanesid bercampur dengan Ras Monggolid yang datang dari utara pada sekitar 2.000 tahun yang lalu (Lansing et al., 2007). Percampuran genetis ini menghasilkan percampuran ciri fisik keduanya yang dapat diamati pada populasi aktual masa kini pada daerah tersebut.

\section{Jejak Austronesia di Kepulauan Nusantara}

Dominasi Ras Australomelanesid pada pertengahan pertama Kala Holosen di Nusantara tampaknya tidak diragukan lagi,

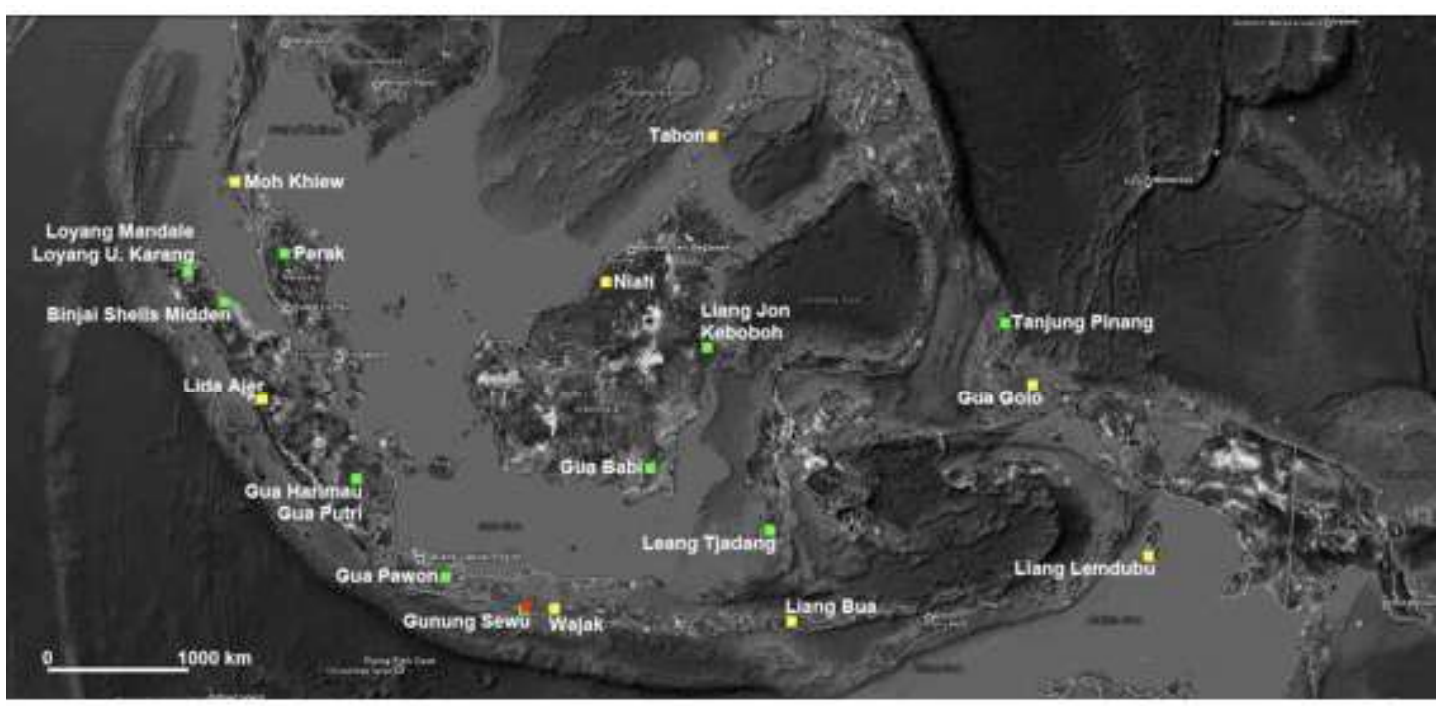

Gambar 1. Peta persebaran situs manusia modern di Nusantara (Keterangan $:$ Kuning $=$ Akhir Plestosen, Hijau $=$ Holosen $)$. 
terutama di separuh wilayah barat, seperti ditampakkan oleh penemuan di Sumatra, Jawa, hingga akhir-akhir ini di Kalimantan Selatan (Widianto, 2002, 2009; Widianto et al., 1997). Data pertanggalan sementara mengindikasikan populasi ini sudah hidup di wilayah ini sejak sekitar 13.000 tahun yang lalu (T. Simanjuntak, 2002), untuk kemudian pada sekitar 4.000 tahun lalu, secara perlahan digantikan oleh populasi baru, penutur Austronesia (Matsumura et al., 2018). Dalam perspekstif biologis, eksistensi penutur Austronesia ini sangat berkaitan erat dengan Ras Monggolid, yang di Asia Tenggara Kepulauan disebut sebagai Ras Monggolid Selatan, dengan ciri fisik, darah, dan ciri lainnya yang membentuk suatu kompleks ciri yang khas (Jacob, 2002). Patut diketahui, populasi ini cukup berbeda dengan Ras Monggolid yang berkembang di China dan Jepang yang disebut Ras Monggolid Utara, yang memiliki warna kulit yang lebih terang, mata yang lebih sipit, dan rambut yang lebih lurus.

Suatu hal yang menarik bahwa data rangka manusia dari berbagai situs menunjukkan arus genetik Ras Monggolid tidak berhasil menembus wilayah Papua dan pulau-pulau lain yang berdekatan di Indonesia bagian timur. Di kawasan ini sisa-sisa manusia lebih didominasi oleh ciriciri Australid - Melanesid - dan Tasmanid (yang telah punah), yang merupakan subras Arafurid (Jacob, 2002). Sementara dari penelitian terhadap sisa-sisa manusia di Asia Tenggara dan Pasifik, Howells (1973) mengidentifikasi kemiripan antara spesimen dari Polinesia dan Mikronesia dengan ciri fenotipus Ras Monggolid Selatan, dan menyimpulkan bahwa penduduk di Pasifik tersebut merupakan keturunan Ras Monggolid Selatan. Mereka bukan keturunan dari Ras Monggolid Utara, apalagi terkait dengan penduduk Australid, Melanesid, ataupun Papua Nugini. Jika tafsiran ini benar, kemungkinan para migran Ras Monggolid Selatan memang telah menggeser penduduk Ras Australomelanesid yang dulunya mendiami kawasan Indonesia Timur (kecuali wilayah Papua dan sekitarnya yang tetap dihuni Ras Australomelanesid) dan menyebar ke arah Pasifik (von Koenigswald, 1952).

Siapakah para penutur bahasa Austronesia itu? Dinyatakan sebagai populasi berciri Ras Monggolid, mereka dikenal sebagai produk akhir sub-spesies dari Homo sapiens. Mereka lah para pelaut ulung di samudra, yang menaklukkan pulau demi pulau untuk mengenalkan teknik pertanian awal di kawasan ini, dengan memproduksi kapak persegi dan kapak lonjong, pembuatan gerabah berslip merah, dan mendomestikasi binatang dan tumbuhan. Di tangan merekalah subsistensi berburu dan meramu yang telah berusia hampir 2 juta tahun, diubah secara drastis menjadi pola menetap dengan bertani dan menjinakkan binatang, disebut sebagai Revolusi Neolitik (Bellwood, 2005).

\section{- Ciri Fisik Ras Monggolid}

Dibandingkan dengan Ras Australomelanesid pendahulunya, maka bangun tengkorak Ras Monggolid menunjukkan proses brachysefalisasi dan grasilisasi general yang sangat signifikan. Oleh karena itu, ciri tengkorak Ras Monggolid adalah brachysefal, dengan kapasitas tengkorak rata-rata $1.400 \mathrm{cc}$. Atap tengkoraknya tinggi dan bundar, tidak terdapat lunas sagittal maupun depresi parasagittal pada bagian tengahnya. Bagian dahi terlihat lebih vertikal, dengan reduksi torus supra-orbitalis dan makin menghilangnya glabella, arcus superciliaris, maupun 
sulcus supra-toralis. Di bagian parietal terlihat dinding yang membundar, dengan tonjolan parietal yang berkembang baik dan merupakan letak dari lebar maksimal tengkorak. Tidak terdapat depresi prelambdatik di bagian belakang tengkorak, sehingga profil occipital berbentuk bundar tanpa sulcus occipitalis, dan sering terlihat multiplikasi tulang Inca di sekitar lambda. Situasi morfologi tengkorak yang demikian tersebut menunjukkan perbedaan yang sangat mencolok apabila dibandingkan dengan karakter yang terlihat pada, Ras Australomelanesid. Postur tubuh, sekaligus biometrik tulang lainnya, juga menunjukkan grasilisasi yang sangat signifikan di lingkungan Ras Monggolid, karena pada Ras Australomelanesid mempunyai ukuran tulang komponen rangka dan postur yang lebih tinggi dan kekar.
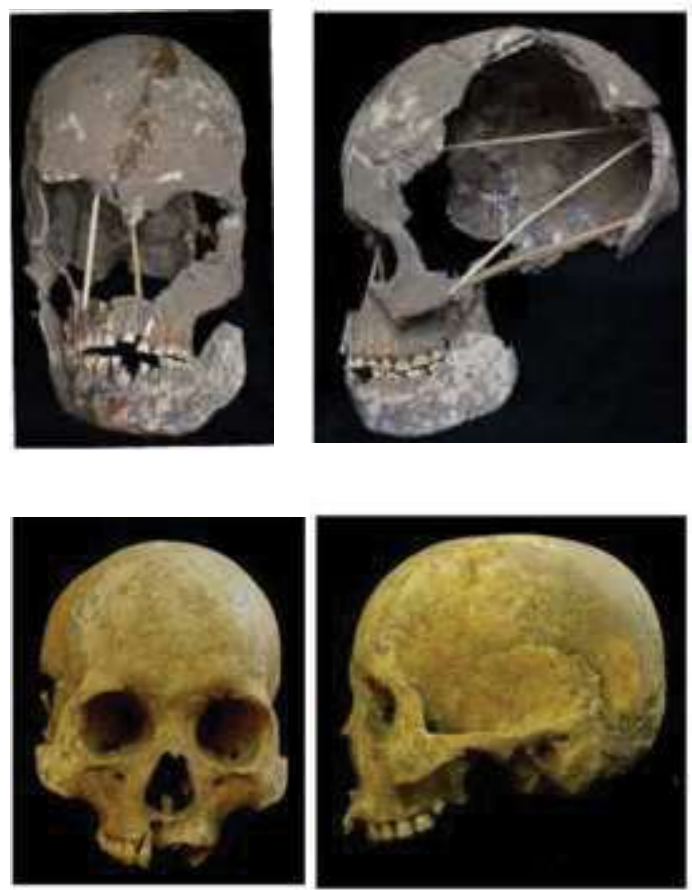

Gambar 2. Tengkorak Australomelanesian, 6.500 BP (Atas) dan Austronesian (Bawah), 2.500 BP dari Gua Harimau (Matsumura et al., 2016)
Ciri lain dari Ras Monggolid yang sangat dominan adalah pada muka yang rata dan lebar. Lebar dan ratanya muka ini terutama juga berkaitan dengan proses grasisilisasi dari karakter super-struktur tengkorak, termasuk prognathisma yang semakin menghilang. Muka lebar juga disebabkan oleh proyeksi lateral tulang malar, dilengkapi pula dengan lekukan nasion yang tidak dalam, akar nasal dangkal, dan palatinus sempit. Orbit mata berbentuk persegi yang lebar dan rendah, disertai dengan margin infraorbital yang bundar. Sejalan dengan proses brachysefalisasi dan grasilisasi tersebut, maka terjadi pula reduksi alat-alat kunyah. Maxilla dan mandibula semakin mengecil, yang diikuti juga oleh ukuran gigi yang semakin ramping, dan sering terlihat bentuk tembilang (shovel-shape) pada gigi seri atas. Fossae gigi taring semakin hilang, disertai oleh proses agenesis pada geraham terakhir (M3), antara lain melalui proses reduksi pada hypoconulid. Tidak terdapat perkembangan nyata dari torus mandibularis maupun torus lateralis, sehingga rahang atas dan bawah terlihat lebih ramping. Kondisi reduksi alat-alat mastikasi tersebut menyebabkan semakin hilangnya ciri prognathisme dan semakin datarnya muka.

\section{- Jejak Austronesia di Pulau Kalimantan}

Di kawasan karst Mangkalihat (Gunung Marang di barat laut Sangata, Kalimantan Timur), terdapat penemuan sisa manusia, peralatan hidup, dan berbagai lukisan goa dari sekitar 3.500 tahun lalu di Goa Kaboboh dan Goa Tewet (Chazine, 2005). Di goa ini, yang terletak sekitar 60 meter di atas muka tanah dengan lereng yang sangat curam, telah ditemukan dua buah kubur berciri Ras Monggolid. Kubur pertama terletak di pintu masuk, berupa kubur individu muda, 
yang berdasarkan gigi-geliginya yang cukup lengkap, merupakan kubur anak-anak. Lebih ke dalam, ditemukan kubur yang hampir lengkap dengan posisi terlipat, yang ditaburi cangkang-cangkang siput air tawar, bersama alat-alat batu dari bahan kalsedon. Tengkoraknya tidak lagi ditemukan. Kedua individu tersebut menunjukkan postur dan ukuran gigi yang ramping.

Di Liang Jon, sebuah goa yang berdekatan dengan Goa Kebaboh, ditemukan banyak alat-alat serpih dari kalsedon, tulang belulang binatang, cangkang air tawar dan laut, pecahan-pecahan gerabah, maupun oker-oker merah. Sebuah rangka manusia ditemukan membujur hanya pada kedalaman $60 \mathrm{~cm}$ dari permukaan tanah. Kepalanya sudah hilang, akan tetapi digantikan dengan segumpal batu. Situasi penguburan seperti ini mirip dengan yang ditemukan di Teouma, Vanuatu, daerah Kaledonia Baru di Pasifik (Valentin, Bedford, Buckley, \& Spriggs, 2010). Gerabah Lapita menjadi ciri utama gerabah-gerabah yang ditemukan di kedua situs terakhir, yang juga ditemukan di Goa Batuaji, Goa Unak dan Liang Kairim. Jejakjejak budaya yang melimpah di berbagai goa tersebut merupakan bukti kuat tentang hunian prasejarah di Tanjung Mangkalihat.

Situasi geografis menunjukkan bahwa Tanjung Mangkalihat merupakan lokasi di Kalimantan yang berjarak paling dekat dengan Sulawesi, hanya sekitar 50 kilometer jika dihitung dari Tanjung Dondo, dekat Tolitoli. Alur migrasi bangsa Austronesia awal ini pun kemudian menjadi lebih gamblang untuk direkonstruksi. Dalam pergerakan dari utara ke selatan melalui jalur TaiwanFilipina-Sulawesi sejak 6.000 tahun yang lalu, pada saat mereka sampai di Tanjung Dondo di dekat Toli-toli, ada percabangan yang bergerak dan menyeberang ke Kalimantan, hingga tiba di kawasan Gunung
Marang, pada sekitar 3.500 tahun silam. Di lain pihak, dari Tanjung Dondo di Sulawesi, kelompok selebihnya tetap melanjutkan perjalanan ke selatan, hingga mencapai daerah Sulawesi Selatan pada sekitar 3.000 tahun silam, dan menetap di goa-goa daerah Maros dan Pangkep (Widianto, 2010).

\section{- Jejak Austronesia di Pulau Sumatra}

Padang Bindu adalah nama sebuah desa di Kecamatan Semidang Aji, yang terletak sekitar 25 kilometer di sebelah barat laut Baturaja, Sumatra Selatan. Setidaknya tiga buah gua yang sangat potensial telah digali, yaitu Pondok Selabe, Gua Pandan, dan Gua Harimau, serta Gua Putri. Tiga buah gua pertama telah telah dieksplorasi secara intensif oleh Pusat Penelitian Arkeologi Nasional selama beberapa tahun terakhir, sementara Gua Putri, telah digali oleh Balai Arkeologi Provinsi Sumatra Selatan antara tahun 2006-2008 (T. Simanjuntak, 2016).

Gua Putri berada di sebuah bukit karst setinggi lebih dari 50 meter dari permukaan tanah. Nyaman untuk dihuni karena konfigurasi ruang yang lurus dan tidak berkelok-kelok, mulut gua yang lebar dan terletak di sisi timur, penetrasi sinar matahari yang langsung dengan intensitas cukup tinggi, dan berada di dekat aliran Sungai Semuhun. Tiga tingkatan gua menunjukkan jejak-jejak mereka yang sangat sarat. Alat-alat serpih, terutama dari obsidian, ditemukan di setiap perlapisan, akan tetapi sisa-sisa manusia hanya ditemukan di ceruk depan pintu masuk lantai dasar. Fragmen tengkorak dan tulangtulang panjang sangat segera hadir, hanya sekitar $30 \mathrm{~cm}$ dalamnya dari permukaan tanah sekarang. Mereka lah sang Ras Monggolid penghuni real estate prasejarah ini, yang telah menguasai alam sekitarnya sejak 3.000 tahun yang lalu (Widianto, 2010). 
Gua Pondok Selabe berkuran jauh lebih kecil, pada relung bukit karst yang sama. Tiga perlapisan tanah ditunjukkan pada kotak penggalian, yang menunjukkan kronologi hunian dari 4.500 hingga 1.000 tahun yang lalu, dari fase akhir pre-neolitik hingga masuk periode sejarah. Jenis temuan budayanya yaitu serpih-serpih obsidian dan gerabah berhias dari tingkatan neolitik, dan pada lapisan atasnya, ditemukan alatalat logam dan periuk. Beberapa individu manusia berciri Ras Monggolid ditemukan pada lapisan kedua dengan usia sekitar 2.700 tahun yang lalu, yang dikuburkan secara membujur. Selain pada kotak-kotak penggalian di dalam gua, sisa-sisa manusia juga ditemukan di penggalian depan teras gua, sehingga aspek penguburan manusia pada periode Pondok Selabe ini dilakukan di dalam dan luar gua (Forestier, Driwantoro, Guillaud, \& Siregar, 2006).

Gua Harimau mempunyai ruang yang lebar dan kering sepanjang masa, dengan sungai yang mengalir tepat di depan gua, meski keletakannya berada sekitar 40 meter di atas aliran sungai. Temuan unsur budaya tidak berbeda dengan Gua Putri dan Pondok Selabe, yaitu alat-alat serpih yang bercampur dengan gerabah. Hanya saja, alat-alat serpih di Gua Harimau lebih banyak dibuat dari batu rijang dibandingkan obsidian. Suatu hal yang menakjubkan adalah ditemukannya sekitar delapan puluhan individu manusia, dengan orientasi rangka ke arah timur (kepala) barat (kaki) (Noerwidi et al., 2016).

Selain pada beberapa gua-gua prasejarah, data tentang sisa-sisa manusia pada pertengahan kedua Kala Holosen juga dapat ditemukan pada situs-situs kubur tempayan. Situs-situs ini ditemukan di Padang Sepan dan Muara Payang, juga di Desa Lesungbatu, Muara Danau, Tebingtinggi di Sumatra Barat seperti dilaporkan oleh J.C Noorlander (van Heekeren, 1958). Apabila dilihat dari temuan artefaktual yang umum dipakai sebagai bekal kubur pada kubur tempayan yang berupa benda-benda neolitik, gerabah, dan logam, maka kubur tempayan tersebut mempunyai kisaran periode antara akhir neolitik hingga paleometalik. Mereka lah wakil dari Ras Monggolid yang hidup antara 2.000-1.500 tahun yang lalu. Salah satu kemungkinan, mereka lah pencipta budaya megalitik di dataran tinggi Sumatra, Pagar Alam, yang tersebar di sekeliling Gunung Dempo, berupa dolmen dan kubur peti batu. Para Ras Monggolid yang dikuburkan di kubur tempayan tersebut mungkin dapat pula dikaitkan dengan menhir-menhir di Lima Puluh Koto, Sumatra Barat (Widianto, 2009).

\section{- Jejak Austronesia di Pulau Jawa}

Penemuan jejak-jejak Ras Monggolid dalam permukiman gua juga ditemukan di Jawa, antara lain Gua Braholo, Song Keplek, dan Song Tritis di Gunung Sewu (Widianto, 2003, 2004). Invididu Keplek 5 berusia $3.200 \pm 50 \mathrm{BP}$ mencirikan individu Ras Monggolid (Noerwidi, 2017). Jika pertanggalan ini benar, maka kemungkinan ras Ras Monggolid menghuni gua ini setelah ras Ras Australomelanesid yang terakhir lenyap pada 4.000 tahun lalu. Di Gua Braholo, indikasi adanya Ras Monggolid juga terlihat pada Braholo 4, yang secara stratigrafis merupakan individu paling muda, karena terletak di lapisan paling atas. Meski tengkoraknya tidak ditemukan, individu ini ditafsirkan berkarakter Ras Monggolid, dilihat dari ukuran tulang anggota badan dan postur tubuh yang ramping, dan lokasi penemuannya pada lapisan atas dengan pertanggalan yang relatif lebih muda (Widianto, 2002). 
Hal yang hampir sama juga ditunjukkan oleh Tritis 1, sebuah rangka manusia yang ditemukan di Song Tritis, sebuah gua hunian pre-neolitik yang berjarak sekitar 3 kilometer di sebelah selatan Gua Braholo. Rangka tersebut terletak di Lapisan 2, berada di antara lapisan gerabah berusia $1.100 \pm 180 \mathrm{BP}$ dan lapisan abu sisa perapian berusia $2.860 \pm$ 150 BP (Widianto, 2004). Tritis 1 merupakan sebuah rangka hasil penguburan primer yang sangat lengkap dengan calvarium, mandibula, dan seluruh gigi-geliginya yang terkonservasi dengan baik. Meski dikubur secara terlipat, Tritis 1 tidak menunjukkan ciri-ciri Ras Australomelanesid. Mandibula tergolong grasil, gigi-geligi berukuran kecil, dan postur maupun ukuran tulang anggota badannya ramping. Ditafsirkan bahwa Tritis 1 adalah wakil Ras Monggolid yang hidup di Song Tritis pada sekitar 2.500 tahun lalu (Widianto, 2004).

Selain pada beberapa gua-gua prasejarah, data sisa manusia pada pertengahan kedua Kala Holosen juga dapat ditemukan pada situs-situs kubur tempayan. Situs-situs kubur tempayan yang cukup menonjol eksistensinya dan telah ditemukan di beberapa tempat di tepi pantai, yaitu di Anyer Lor (Banten) dan Plawangan (Rembang, Jawa Tengah) (van Heekeren,
1958). Berdasarkan temuan artefaktual yang umum dipakai sebagai bekal kubur pada kubur tempayan yang berupa benda-benda neolitik, gerabah, dan logam, maka kubur tempayan tersebut mempunyai kisaran periode antara neolitik hingga paleometalik.

Di Anyer Lor (Banten) rangka manusia dikubur dalam posisi terlipat, dengan bekal kubur berupa piring dan mangkuk tanah liat, tanpa benda-benda perunggu (van Heekeren, 1958). Selain itu juga ditemukan rangka membujur telungkup dan tengadah, seperti yang masih dilakukan di dekat Danau Batur dan Buleleng Timur (van Stein Callenfels 1940). Salah satu kubur tempayan menyisakan tengkorak yang rendah tetapi bertulang tebal $(10,4 \mathrm{~mm})$, mandibula kekar namun dengan ukuran gigi normal, mungkin milik seorang laki-laki. Van Heekeren menganggap bahwa kubur Anyer merupakan kubur proto-histori, yang berasal dari periode antara tahun 200500 AD (van Heekeren, 1956). Sebuah mandibula yang diteliti oleh Jacob (1964), diidentifikasi sebagai sebuah mandibula dolichognathic dari seorang wanita dewasa berusia sekitar 20 tahun. Corpus yang sangat tinggi dan tebal tetapi dengan ukuran gigi normal, menunjukkan ciri-ciri Ras Australomelanesid, yang muncul lagi pada kubur tempayan di pantai Jawa Barat.

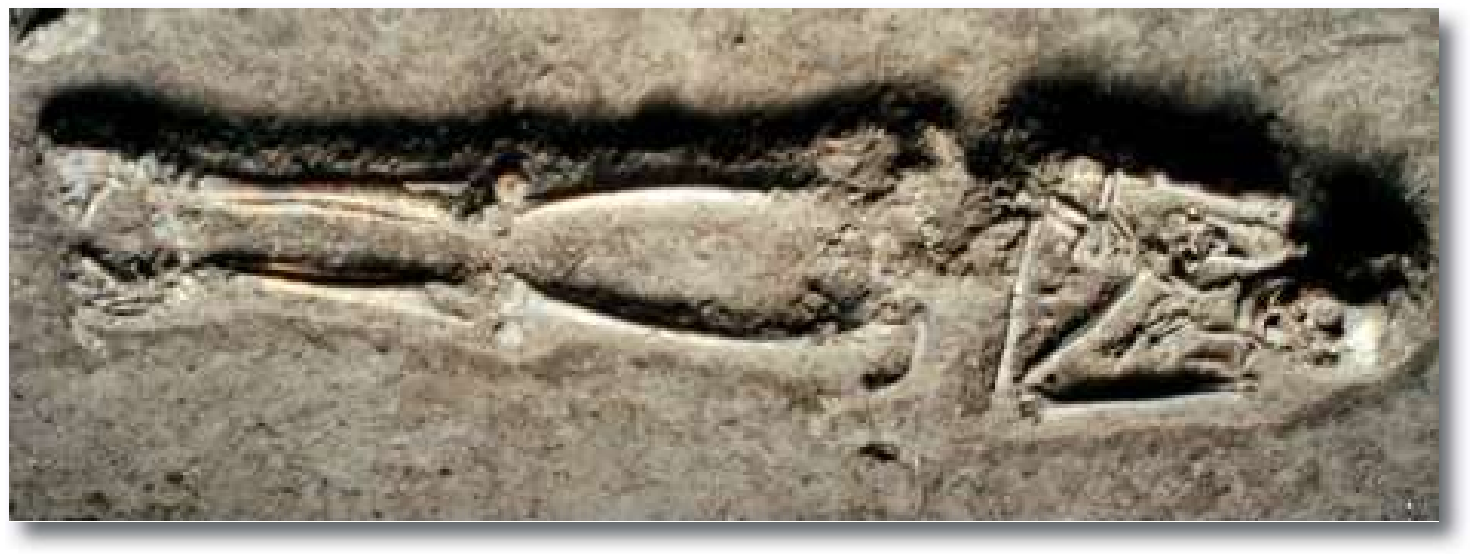

Gambar 3. Kubur terlentang individu Song Keplek 5 (T. Simanjuntak, 2002). 
Situasi agak berbeda ditampilkan dari situs kubur tempayan di Plawangan, tepi pantai Rembang (Jawa Tengah). Situs kubur yang disertai dengan bekal kubur berupa manik-manik, benda-benda dari perunggu dan besi, serta barang-barang tanah liat ini merupakan situs kubur yang cukup luas dan padat, yang telah menghasilkan paling tidak 40 individu (Soegondho, 1990). Berdasarkan bekal kuburnya, situs ini diperkirakan merupakan variasi dari situs kubur tempayan yang berkembang pada masa akhir prasejarah di Indonesia. Ciriciri fisiknya menunjuk ciri Ras Monggolid (Boedhisampoerno, 1990). Tengkoraknya merupakan tengkorak brachysefal, berbentuk bulat, agak tinggi, dengan wajah lebar tetapi datar, tulang hidung datar, lubang mata sedang, dan prognathisme sedang. Rahangnya tidak kekar, dengan ukuran gigi yang sedang dengan bentuk tembilang pada gigi depan, menunjukkan rotasi geraham dan penjejalan gigi pada individu tertentu. Rangka infra-kranial menunjukkan postur yang kecil hingga sedang.

\section{- Jejak Austronesia di Pulau Sulawesi}

Contoh lain dari eksistensi Ras Monggolid yang hidup di gua prasejarah adalah rangka dari Leang Cadang, di Soppeng, Sulawesi Selatan. Sisa manusia yang berupa mandibula, maxilla dan lebih dari 2.700 gigi lepas tersebut berkaitan dengan budaya Toala Atas berusia sekitar 4.000 tahun (van Heekeren, 1941). Sebagian besar gigi-geligi tersebut, terutama pada gigi seri dan taring (lebih dari $85 \%$ pada gigi seri atas dan lebih dari $32 \%$ pada gigi seri bawah) menunjukkan bentuk tembilang yang nyata, suatu karakter kuat dari Ras Monggolid (Jacob, 1967), yang berdasarkan dimensinya, juga sebanding dengan gigigeligi dari Bola Batu, yang terletak di sebelah tenggara Leang Cadang. Dalam hal ini, Leang Cadang dan Bola Batu merupakan situs-situs di Sulawesi yang telah dihuni oleh Ras Monggolid pada sekitar 4.000 tahun yang lalu.

Di Sa'bang, sekitar 50 kilometer di sebelah utara Paloppo, ditemukan pula 10 kubur sejenis yang berasosiasi dengan benda-benda gerabah, pemukul kulit kayu, batu giling, dan mata panah besi. Ditafsirkan kubur-kubur tersebut merupakan kubur sekunder (van Heekeren, 1958). Kubur tempayan juga ditemukan di dekat kompleks megalitik Bada, Sulawesi Tengah, akan tetapi tidak diketahui apakah kubur-kubur merupakan bagian dari budaya megalitik tersebut, atau berdiri sendiri.

\section{- Jejak Austronesia di Pulau Bali dan Kepulauan Sunda Kecil}

Senada dengan temuan sisa manusia dari Plawangan adalah situs kubur tempayan Gilimanuk (Bali). Di suatu dataran setinggi 5 meter di atas permukaan laut, di tepi pantai Gilimanuk, telah ditemukan kubur-kubur tempayan. Lebih dari 100 individu manusia ditemukan di situs ini dalam berbagai tata cara penguburan yang meliputi kubur primer (tunggal, rangkap bertumpuk dengan sikap rangka membujur, semi terlipat, terlipat, dorsal, dan telungkup), kubur sekunder, kubur campuran, dan kubur tempayan sepasang. Lebih dari 100 individu manusia ditemukan pada situs ini, yang sebagian besar rangkanya dalam keadaan utuh. Kubur-kubur tersebut disertai dengan bekal-bekal kubur berupa periuk, perhiasan (manik-manik dan gelang), benda-benda perunggu dan besi, binatang-binatang korban (babi, anjing, dan unggas), dan juga benda peralatan seharihari seperti periuk, mata kail, maupun alat dari cangkang kerang (Soejono, 1977). 

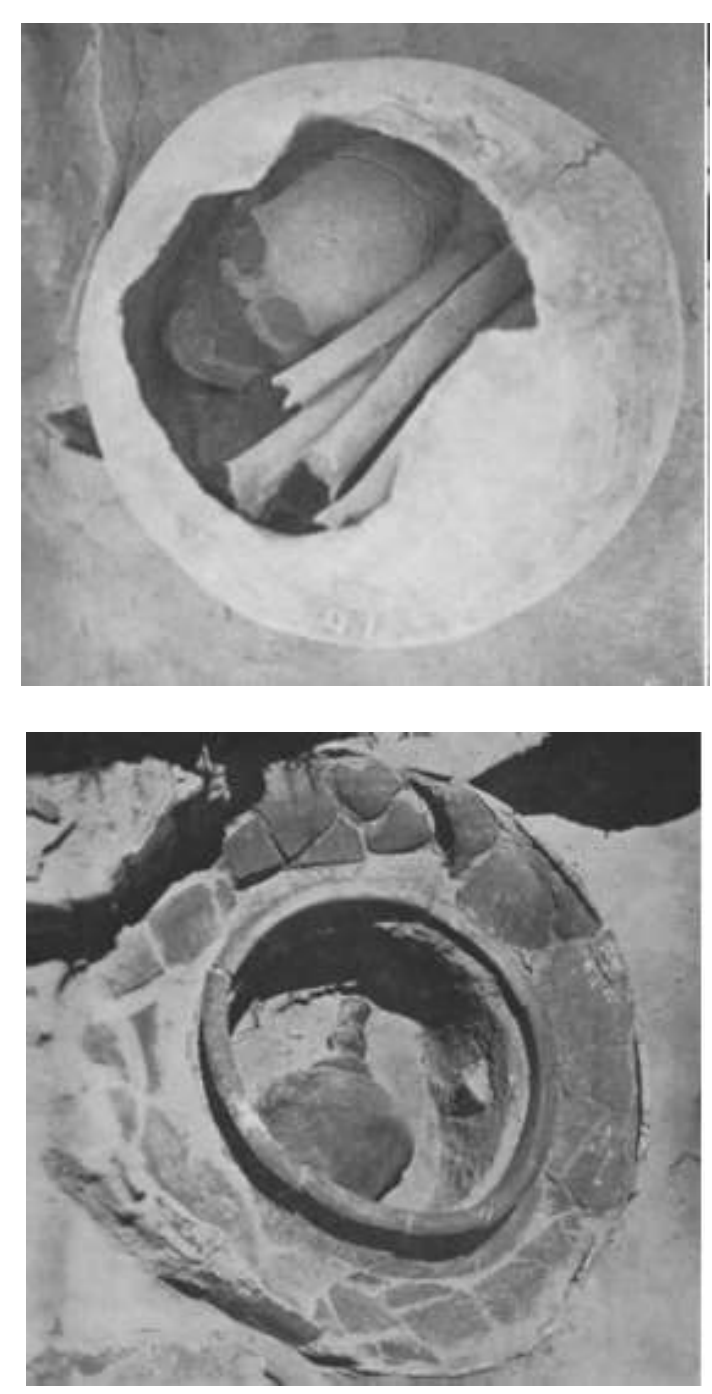

Gambar 4. Sisa manusia (atas) dan bekal kubur (bawah) dari situs Melolo, Sumba Timur (van Heekeren, 1958).

Terdapat dua tingkatan okupasi manusia pada situs ini, yang paling muda pada kedalaman 50-60 $\mathrm{cm}$ menghasilkan pertanggalan $1.650 \pm 55 \mathrm{BP}$, dan okupasi yang lebih tua, pada kedalaman $150 \mathrm{~cm}$, menghasilkan angka $1.850 \pm 55$ Bp sampai $1.800 \pm 85$ BP (Soejono, 1977). Berdasarkan pertanggalan tersebut, maka Situs Gilimanuk ditafsirkan merupakan situs kubur tempayan pada akhir masa prasejarah di Indonesia. Jacob (1967) menyimpulkan berdasarkan ciri-ciri pada tengkorak, muka, dan gigi- geliginya bahwa manusia Gilimanuk merupakan populasi Ras Monggolid. Manusia Gilimanuk yang hidup di tingkatan paleometalik tersebut diduga merupakan nenek moyang penduduk Bali pada masa sekarang (Sudoyo et al., 2004).

Kubur tempayan juga ditemukan di Melolo (Sumba Timur) oleh A.C Kruyt, yang selanjutnya diekskavasi oleh L. Dannenberger dan Rodenwaldt. Mereka kemudian mengirimkan 34 tengkorak dari penggalian tersebut kepada J.P Kleiweg de Zwaan dan juga C.A.R.D Snell di Surabaya. Sisa manusia tersebut tidak ditemukan secara lengkap, umumnya berupa tengkorak, dengan atau tanpa mandibula, kadangkadang disertai pula dengan tulang-tulang anggota badan, sehingga diperkirakan kompleks kubur sekunder (van Heekeren, 1958). Bekal kubur berupa manik-manik cangkang dan batu, gelang dan cincin kerang, beliung persegi, dan gerabah. Artefaktual ini mengidikasikan kubur tempayan Melolo berasal dari konteks neolitik. Hasil studi Snell terhadap sisa-sisa manusia Melolo menunjukkan kelompok tengkorak mesodolichosefal, dan merupakan percampuran antara ciri Palaeo-Melanesid/Negroid dan Ras Monggolid (Snell, 1948).

\section{Muncul dan Berkembangnya Populasi} Ras Monggolid

Penemuan-penemuan di atas menjelaskan kepada kita bahwa pada pertengahan keduaKala Holosen hingga akhir masa prasejarah di Indonesia, tampaknya ras Ras Monggolid telah benar-benar menguasai seluruh kawasan kepulauan, kecuali di Papua dan pulau-pulau di bagian timur Indonesia yang lebih didominasi oleh PapuaMelanesid (Bellwood, 2017). Penemuanpeneman tersebut -baik pada situs-situs 
gua ataupun situs-situs kubur tempayan yang umumnya menempati wilayah pesisirtelah memberikan gambaran yang sangat penting bagi mobilitas Ras Monggolid sejak kedatangannya pertama kali di Kepulauan Nusantara. Di sini kita melihat terjadinya dinamika penghunian, dari Ras Australomelanesid yang datang terlebih dahulu, secara lambat laun digantikan oleh Ras Monggolid (Matsumura et al., 2017).

Gejala proses hunian di atas menjadi lebih menarik pada 37 individu manusia yang ditemukan di Gua Kepah, pemukiman yang berkonteks budaya bukit sampah kerang bertarikh pre-neolitik. Ciri-ciri yang dominan pada sisa manusia tersebut adalah percampuran antara Ras Monggolid dan Ras Australomelanesid (Jacob, 1967). Apabila diperhitungkan dengan eksistensi Ras Monggolid, Melanesid, dan Australid saat ini, maka terlihat adanya pengaruh hibridasi dan evolusi yang bekerja bersama. Jika dikaitkan dengan hibridasi sejenis pada spesimen Wajak, ada kemungkinan unsur Ras Monggolid telah ada di Nusantara sejak awal Holosen, dan kedatangannya di Indonesia mungkin jauh lebih awal dari yang diduga Bentuk hibridasi pada akhir Plestosen dan awal Holosen kemudian semakin berkurang, dan menjadi dominan di Ras Monggolid pada 3.500 tahun silam, yang dibuktikan oleh individu Keplek 5 dari Gunung Sewu (Noerwidi, 2012). Dalam kuantitas data yang jauh lebih kecil dibandingkan dengan proses "replacement" tersebut, maka kasus hibridasi dari Wajak dan Gua Kepah dapat dipakai sebagai indikasi "evolusi lokal" tentang munculnya Ras Monggolid di wilayah ini (Jacob, 1967).

Tampaknya proses penghunian gua yang marak dilakukan oleh Ras Australomelanesid pada awal Kala Holosen tersebut tidak dengan serta merta digantikan oleh hunian di tempat terbuka pada awal neolitik seiring dengan datang dan dominasi Ras Monggolid di Indonesia. Dengan kata lain, Ras Monggolid tidak secara otomatis mendiami hunian terbuka di saat mereka datang pertama kali di Indonesia, akan tetapi mereka masih menggunakan guagua hunian sebagai tempat tinggal pertama mereka. Selain dibuktikan secara langsung

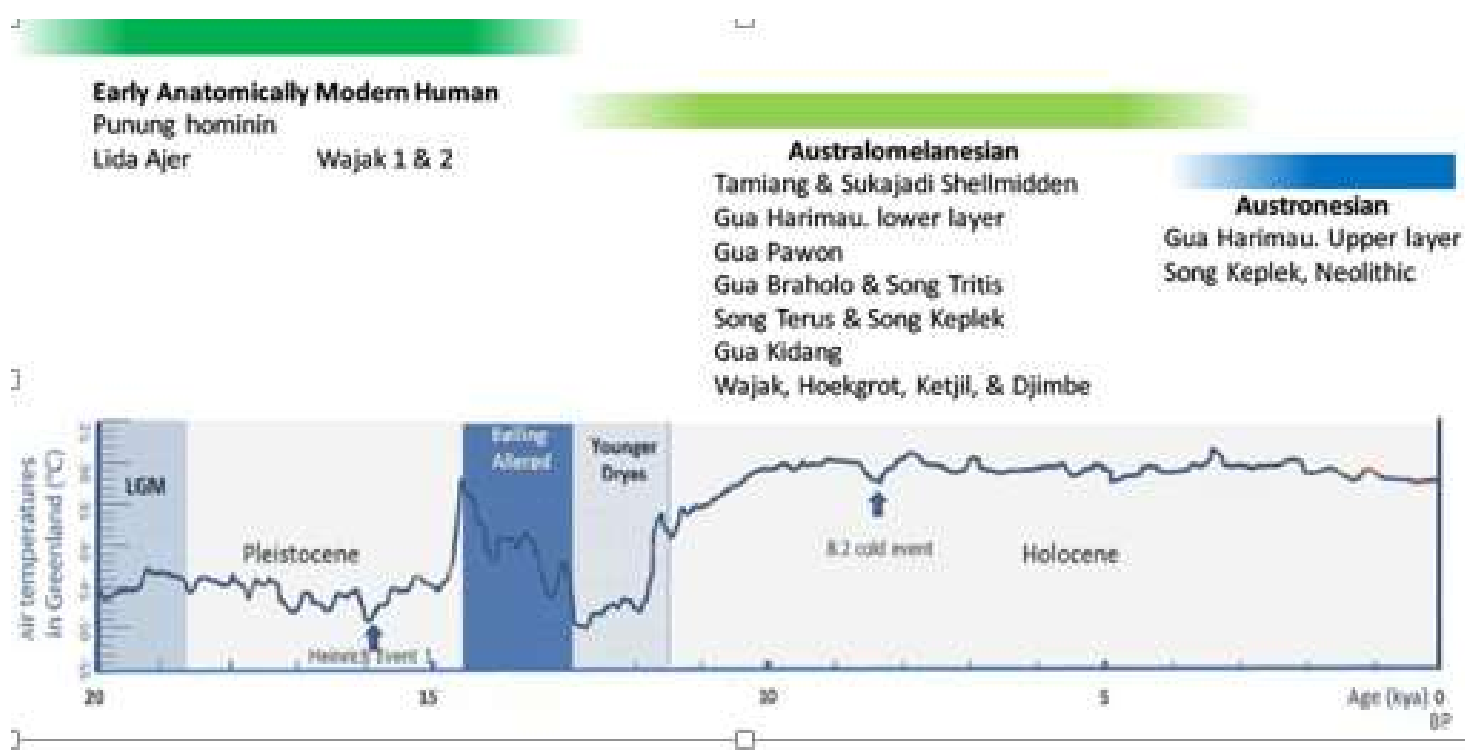

Gambar 5. Bagan kronologi penghunian Kepulauan Nusantara oleh manusia modern (Noerwidi, 2020). 
oleh penemuan sisa-sisa manusia berciri Ras Monggolid di Gua Braholo, Song Keplek, dan Song Tritis misalnya, jejak-jejak mereka di gua-gua hunian secara tidak langsung juga ditunjukkan oleh adanya lapisan gerabah di bagian atas yang umum ditemukan ( $\mathrm{T}$. Simanjuntak, 2002).

Kapan manusia Ras Monggolid tersebut benar-benar keluar meninggalkan gua dan menempati hunian mereka di lokasi terbuka, tentu berbeda-beda di setiap daerah. Data pertanggalan yang diperoleh sejauh ini dari Song Keplek dan Gua Braholo mengindikasikan perpindahan ke alam terbuka di wilayah Gunung Sewu terjadi di sekitar 2000 tahun lalu dengan mengembangkan industri beliung persegi dan mata panah (T. Simanjuntak, 2002). Data dari daerah lain belum diperoleh secara pasti. Selain oleh minimnya situs hunian neolitik, ketidakpastian tersebut juga berkaitan dengan masih terbatasnya data sisa manusia dari situs neolitik yang ditemukan.

Jacob (1967) menyebutkan konteks Melanesid bagi sisa manusia dari Situs Kalumpang di Sulawesi, sehingga pendukung budaya neolitik di Kalumpang dikaitkan dengan proses migrasi yang berkembang di wilayah Indonesia bagian timur. Sementara keterbatasan penemuan sisa manusia dari situs-situs neolitik berbagai wilayah Nusantara menyulitkan kita untuk mengetahui proses persebarannya secara lebih jelas. Data tentang populasi ini baru ditemukan pada kubur-kubur tempayan di tepi pantai, dari periode yang lebih kemudian (sekitar awal Masehi), di mana teknologi paleometalik telah berkembang pesat pada akhir masa prasejarah. Bukti-bukti rangka tersebut menunjukkan dominasi Ras Monggolid yang kuat pada situs Plawangan dan Gilimanuk, akan tetapi ciri Ras Australomelanesid masih cukup jelas terlihat pada kubur tempayan di Anyer, sementara percampuran PalaeoMelanesid dan Ras Monggolid terlihat pada manusia Melolo.

Situasi ini memberikan pengertian kepada kita bahwa di satu pihak Ras Australomelanesid masih tetap eksis hingga awal Masehi di Nusantara, sementara di lain pihak, Ras Monggolid sudah menunjukkan tanda-tanda kehadirannya di Song Keplek sekitar 3.500 tahun yang lalu. Oleh karenanya, eksistensi kedua populasi tersebut tidak dapat dipisahkan secara tegas, akan tetapi terdapat kelenturan arus genetik tersendiri yang mengalir di wilayah Nusantara selama Kala Holosen, dan bahkan sejak akhir Kala Plestosen, yang memungkinkan keduanya eksis bersamaan dan melampaui periode teoritisnya (Simanjuntak \& Widianto, 2012).

\section{SIMPULAN}

Berdasarkan uraian tentang lokasi penemuan rangka manusia berciri Ras Monggolid ini terlihat diaspora yang cukup kompleks. Mereka tidak langsung menghuni daerah terbuka sesuai dengan keahlian mereka di bidang pertanian, akan tetapi masih masuk dan tinggal di dalam goa sambil mempraktekkan aktivitas bertani mereka. Bukti-bukti mengenai tempat tinggal mereka di alam terbuka sangat jarang atau hampir-hampir tidak pernah teridentifikasi disebabkan oleh berbagai faktor. Faktor pertama terkait dengan materi hunian yang tidak tahan lama, misalkan rumah-rumah yang didirikan dari kayu beratap sirap seperti yang selama ini menjadi pemahaman tentang rumah-rumah neolitik.

Faktor kedua-masih terkait dengan pelapukan tadi-adalah faktor iklim. Kepulauan Nusantara merupakan sebuah area luas yang beriklim tropis, matahari bersinar 
seharian penuh, setahun berganti dua musim kemarau dan hujan. Karakter iklim yang demikian tersebut akan mempercepat proses pelapukan organik yang terjadi di wilayah kepulauan ini. Oleh sebab itu, faktor pertama dan kedua di atas menjadi natural agency yang sangat efektif untuk menghancurkan bendabenda organik dengan cepat sehingga tidak sempat terawetkan. Jika hal ini benar, maka sisa permukiman mereka sudah barang tentu tidak bisa lagi diidentifikasi karena sudah lapuk dan tidak berbekas. Selain di dalam goa, pemukiman terbuka neolitik hampir tidak pernah ditemukan, kecuali berbagai kubur mereka di alam terbuka seperti kubur pantai maupun kubur tempayan di dataran tinggi.

SejakawalabadMasehi, paraAustronesia di Kepulauan Nusantara tersebut kemudian berinteraksi dengan para pendatang dari barat, antara lain dari Jazirah Gujarat dan India. Interaksi yang awalnya disebabkan oleh proses perdagangan ini, kelak di kemudian hari, akan sanggup penghadirkan corak budaya tersendiri di kalangan para Austronesia Nusantara ini. Kemahiran dalam bidang pertanian telah diwariskan ke keturunan langsung mereka saat ini, sebagai bangsa yang berlandaskan diri pada sektor pertanian bagi subsistensinya. Di lain pihak, kemampuan penguasaan teknologi bahari oleh para Austronesia sejak awal, juga telah mewarnai salah satu sisi hidup bangsa ini, sejak dini sekali hingga sekarang. Wilayah laut seluas $70 \%$ dan wilayah darat seluas $30 \%$ dari teritorial Kepulauan Nusantara, sangat mendukung pewarisan akan kemahiran sejati para Austronesia awal yang telah hadir di kepulauan ini sejak 4.000 tahun silam, di bidang pertanian dan kelautan. Inilah warisan riil para Austronesia awal, untuk keturunan langsung mereka, para Austronesia akhir. Sebuah diaspora yang memukau dan mewarnai pelangi rasiologi yang terjadi di Kepulauan Nusantara sejak awal sekali, dan telah berkontribusi secara nyata bagi kehadiran sebuah bangsa besar saat ini, Bangsa Indonesia.

\section{DAFTAR PUSTAKA}

Bellwood, P. (2005). First farmers: the origins of agricultural societies. Victoria: Blackwell Oxford.

Bellwood, P. (2014). First Migrants: Ancient Migration in Global Perspective. Retrieved from https://books.google. com/books?hl=en\&lr=\&id=bkOcAg AAQBAJ\&pgis $=1$

Bellwood, P. (2017). First islanders: Prehistory and human migration in Island Southeast Asia. Oxford: John Wiley \& Sons.

Blust, R. A. (2009). The Austronesian Languages (Vol. 602).

Boedhisampoerno, S. (1990). Temuan sisa rangka manusia dari situs kubur paleometalik Plawangan, Rembang, Jawa Tengah. In Proceedings Analisis Hasil Penelitian Arkeologi I, Plawangan: Religi Dalam Kaitannya dengan Kematian, Jilid II.

Chazine, J. M. (2005). Rock art, burials, and habitations: Caves in East Kalimantan. Asian Perspectives, 44(1), 219-230. https://doi. org/10.1353/asi.2005.0006

Choosiri, P. (1996). An analysis of palaeopathological changes in the human skeletal remains from Southern Thailand. Final Report of Excavations at Moh Kiew Cave, Krabi Province, 392-399.

de Vos, J. (1985). Faunal Stratigraphy and Correlation of the Indonesian Hominid Sites. In Ancestors: The Hard Evidence (pp. 215-220). 
Détroit, F., Dizon, E., Falguères, C., Hameau, S., Ronquillo, W., \& Sémah, F. (2004). Upper Pleistocene Homo sapiens from the Tabon cave (Palawan, The Philippines): Description and dating of new discoveries. Comptes Rendus - Palevol, 3(8), 705-712. https://doi. org/10.1016/j.crpv.2004.06.004

Diamond, J. (2013). Guns, germs and steel: a short history of everybody for the last 13,000 years. Random House.

Forestier, H., Driwantoro, D., Guillaud, D., \& Siregar, D. (2006). New data for the prehistoric chronology of south Sumatra. In Archaeology: Indonesian Perspective. RP Soejono's Festschrift. LIPI Press, Jakarta (pp. 177-192). Jakarta: Yayasan Obor Indonesia.

Howells, W. W. (1973). Cranial variation in man: a study by multivariate analysis of patterns of difference among recent human populations. Peabody Museum of Archaeology and Ethnology, Harvard Univ.

Hunt, C. O., Gilbertson, D. D., \& Rushworth, G. (2007). Modern humans in Sarawak, Malaysian Borneo, during Oxygen Isotope Stage 3: palaeoenvironmental evidence from the Great Cave of Niah. Journal of Archaeological Science, 34(11), 1953-1969. https:// doi.org/10.1016/j.jas.2007.02.023

Jacob, T. (1964). A Human mandible from Anjar Urn Field, Indonesia. Journal of the National Medical Association, 56(5), 421-426.

Jacob, T. (1967). Some problems pertaining to the racial history of the Indonesian region. University of Utrech, Netherland.

Jacob, T. (2002). Ras, etni, dan bangsa. In Pertemuan Ilmiah Arkeologi IX (Kediri). Jakarta: Ikatan Ahli Arkeologi Indonesia.

Lansing, J. S., Cox, M. P., Downey, S. S., Gabler, B. M., Hallmark, B.,
Karafet, T. M., ... Watkins, J. C. (2007). Coevolution of languages and genes on the island of Sumba, eastern Indonesia. Proceedings of the National Academy of Sciences, 104(41), 16022-16026.

Matsumura, H., \& Oxenham, M. F. (2014). Demographic transitions and migration in prehistoric East/ Southeast Asia through the lens of nonmetric dental traits. American Journal of Physical Anthropology, 155(1), 45-65.

Matsumura, H., Oxenham, M., Simanjuntak, T., \& Yamagata, M. (2017). The biological history of Southeast Asian populations from Late Pleistocene and Holocene cemetery data. First Islanders: Prehistory and Human Migration in Island Southeast Asia. Wiley Blackwell, Oxford.

Matsumura, H., Shinoda, K., Simanjuntak, T., Oktaviana, A. A., Noerwidi, S., Sofian, H. O., ... Kanzawa-Kiriyama, H. (2018). Cranio-morphometric and aDNA corroboration of the Austronesian dispersal model in ancient Island SoutheastAsia: Support from Gua Harimau, Indonesia. PloS One, 13(6), e0198689.

Matsumura, H., Simanjuntak, T., Oktaviana, A. A., Noerwidi, S., Prastiningtyas, D., Cuong, N. L., ... Hana, M. (2016). Verifying Austronesian Hypothesis from the Skeletal Human Remains from Gua Harimau Site in Sumatera. In Austronesian diaspora: A new Perspective (pp.495-510). Yogyakarta: Gajah Mada University Press.

Noerwidi, S. (2012). Rekonstruksi Aspek Biologis dan Konteks Budaya Rangka Manusia Holosen, Song Keplek 5. Berkala Arkeologi, 32(2), 135-150. Retrieved from http:// berkalaarkeologi.kemdikbud.go.id/ index.php/berkalaarkeologi/article/ view/53/113 
Noerwidi, S. (2017). Using dental metrical analysis to determine the Terminal Pleistocene and Holocene population history of Java. In P. Piper \& D. Bulbeck (Eds.), terra australis 45 (pp. 79-96). Canberra: ANU E Press.

Noerwidi, S. (2020). Diversité des hominines dans l'archipel ouest Indonésien au Quaternaire: une perspective donnée par l'étude du registre fossile dentaire. Muséum national d'Histoire naturelle - Sorbonne Université, Paris.

Noerwidi, S., Prastiningtyas, D., Widianto, H., Aziz, F. A., Putri, A., Senjaya, T., \& Awe, R. D. (2016). The Graves of The Harimau Cave: A Biocultural Study. In T. Simanjuntak (Ed.), Harimau Cave and the Long Journey of OKU Civilization (pp. 152-178). Yogyakarta: Gadjah Mada University Press.

Rizal, Y., Westaway, K. E., Zaim, Y., van den Bergh, G. D., Bettis, E. A., Morwood, M. J., ... Ciochon, R. L. (2019). Last appearance of Homo erectus at Ngandong, Java, 117,000108,000 years ago. Nature, (May). https://doi.org/10.1038/s41586-0191863-2

Sémah, F., Sémah, A. M., Falgueres, C., Detroit, F., Gallet, X., Hameau, S., ... Simanjuntak, H. . (2004). The significance of the Punung karstic area (eastern Java) for the chronology of the Javanese Palaeolithic, with special reference to the Song Terus cave. Modern Quaternary Research of Southeast Asia, 18, 45-62.

Simanjuntak, H. T., \& Widianto, H. (2012). Indonesia dalam Arus Sejarah. Jakarta: PT. Ichtiar Baru van Hoeve.

Simanjuntak, T. (2002). Gunung Sewu in prehistoric times. Gadjah Mada University Press.
Simanjuntak, T. (2016). Harimau Cave and the Long Journey of OKU Civilization. (T. Simanjuntak, Ed.). Yogyakarta: Gadjah Mada University Press.

Snell, C. A. R. D. (1948). Human Skulls from the Urn-field of Melolo, East-Sumba. Acta Neerkandica Morphologiae Normalis et Pathologicae, 6(3), 1-20.

Soegondho, S. (1990). Tinjauan terhadap Situs Plawangan. In Proceedings Analisis Hasil Penelitian Arkeologi I, Plawangan: Religi Dalam Kaitannya dengan Kematian, Jilid II. Jakarta: Departemen Pendidikan dan Kebudayaan.

Soejono, R. P. (1977). Sistim-sistim penguburan pada akhir masa prasejarah di Bali. Dissertation. Jakarta: Universitas Indonesia.

Sudoyo, H., Suryadi, H., Setiadi, W., Adnan, I. A., Sentausa, E., Jusuf, I., ... Marzuki, S. (2004). Studi genetika molekul populasi Austroneia. In Polemik tentang masyarakat Austronesia. Fakta atau fiksi? (pp. 103-119). Jakarta: Lembaga Ilmu Pengetahuan-Direktorat Jenderal Pendidikan Tinggi.

Tryon, D. (1995). Proto-Austronesian and the major Austronesian subgroups. The Austronesians: Historical and Comparative Perspectives, 19-41.

Valentin, F., Bedford, S., Buckley, H. R., \& Spriggs, M. (2010). Lapita burial practices: Evidence for complex body and bone treatment at the teouma cemetery, vanuatu, southwest pacific. Journal of Island and Coastal Archaeology, 5(2), 212-235. https://doi. org/10.1080/15564891003648092

van Bemmelen, R. W. (1949). The geology of Indonesia, Vol. IA: General Geology of Indonesia and Adjacent Archipelagoes. The Hague: Martinus Nijhoff. 
van der Maarel, F. H. (1932). Contributions to the knowledge of the fossil mammalian fauna of Java. Wet. Med. Dienst. Mijnb. Ned. Indie, 15, 1-208.

van Heekeren, H. R. (1941). Over Toala's en de Toala-cultuur (Zuid-Celebes). Natuurwetenschappen Tijdschrift Nederlndsch Indië, 101(8), 229237.

van Heekeren, H. R. (1956). Note on a ProtoHistoric Urn-Burial Site at Anjar, Java. Anthropos, 51(1/2), 194-200. Retrieved from http://www.jstor.org/ stable/40451105

van Heekeren, H. R. (1958). The BronzeIron Age of Indonesia. The Hague: S-Gravenhage.

von Koenigswald, G. H. R. (1935). Die Fossilen Saugetierfaunen Javas. Kon. Akad. Wet., Amsterdam, XXXVIII(2), 188-198.

von Koenigswald, G. H. R. (1952). Evidence of a Prehistoric Australomelanesoid population in Malaya and Indonesia. Southwestern Journal of Anthropology, 8(1), 92-96.

Westaway, K. E., Louys, J., Awe, R. D., Morwood, M. J., Price, G. J., Zhao, J. X., ... Sulistyanto, B. (2017). An early modern human presence in Sumatra 73,000-63,000 years ago. Nature, 548(7667), 322-325. https://doi.org/10.1038/ nature 23452

Widianto, H. (2001). The Perspective on the Evolution of Javanese Homo erectus Based on Morphological and Stratigraphic Characteristics. In T. Simanjuntak, B. Prasetyo, \& R. Handini (Eds.), Sangiran: Man, Culture, and Environment in Pleistocene Times (pp. 24-45). Jakarta: Yayasan Obor Indonesia.
Widianto, H. (2002). Prehistoric inhabitants of Gunung Sewu. Gunung Sewu in Prehistoric Times, 227-248.

Widianto, H. (2003). Sisa manusia dari guagua prasejarah di Gunung Sewu: korelasinya terhadap asal-usul orang Austronesia. In Kongres Ilmu Pengetahuan Nasional VIII. Jakarta: Lembaga Ilmu PengetahuanDirektorat Jenderal Pendidikan Tinggi.

Widianto, H. (2004). Song Tritis: salah satu situs hunian gua prasejarah pada awal Kala Holosen di Gunung Sewu. Yogyakarta.

Widianto, H. (2009). The Dawn of Humanity in Sumatra: Arrival and Dispersal from the Human Remains Perspectives. In D. Bonatz, J. Miksic, D. Neidel, \& M. L. Tjoa-Bonatz (Eds.), From Distant Tales: Archaeology and Ethnohistory in the Highlands of Sumatra in the Highlands of Sumatra (pp. 28-42). Cambridge University Press. https://doi. org/10.1080/01947641003598252

Widianto, H. (2010). Jejak Langkah Setelah Sangiran (Edisi Khusus). Jawa Tengah: Balai Pelestarian Situs Manusia Purba Sangiran. Sragen: Balai Pelestarian Situs Manusia Purba Sangiran.

Widianto, H. (2019). Poros BumiayuPrupuk-Semedo : Migrasi fauna dan manusia tertua di Pulau Jawa. Yogyakarta. Retrieved from http://repositori.kemdikbud. go.id/17582/

Widianto, H., Simanjutak, T., \& Toha, B. (1997). Ekskavasi Situs Gua Babi, Kabupaten Tabalong, Provinsi Kalimantan Selatan. Jakarta: Pusat Penelitian Arkeologi Nasional, Balai Arkeologi Banjarmasin. 


\section{HASIL DISKUSI}

\section{Pertanyaan}

\section{Gunadi (Balai Arkeologi Yogyakarta):}

Gambar cadas milik Austronesia beda dg paparan pa daud. Apa lukisan cadas juga dimiliki oleh austromelanisia

\section{Nenggih (Balai Arkeologi Sumatera Utara):}

Terkait dengan volume isi tengkorak, apakah ada keterkaitan dengan komunikasi yang terjalin di masyarakat Austronesia dengan perkembangan tengkorak?

\section{Lucas (Balai Arkeologi Maluku):}

a. Apakah ada pengelompokan penutur austronesia di Indonesia.

b. Apa startegi bertahan hidup pada saat mereka bermigrasi?

\section{Irsyad (Universtas Indonesia):}

a. Penemuan Oker apakah ada kaitan dengan lukisan gua?

b. Metode dating, masih perdebatan apakah perlu diabaikan?

\section{Jawaban}

1. Lukisan cadas berkembang pesat di Kalimantan, Sulawesi, Indonesia timur dengan motif yang lebih modern. Lukisan cadas yang ditemukan di guagua, dari segi gua dan manusia terlihat bukti adanya austronesia. Tidak pernah ketemu austromelanesid membuat lukisan gua. Mereka membuat alat serpih.

2. Perkembangan otak tidak akan berbalik dalam evolusi kecuali adanya anomali. Migrasi terjadi sebagai akibat dari ledakan penduduk, sehingga mencari daerah yang baru, dan terus berlanjut untuk terus pergi.

3. Teori Migrasi, mereka pergi melawan arus, ketika gagal akan mudah kembali

4. Pertanggalan merupakan suatu yang sensitif, semua proses harus benar agar hasilnya akurat. 